\title{
Mediatized tourist experience: a Brazilian TV newscast conception ${ }^{1}$
}

\author{
Lauro Moraes* \\ Universidade Federal do Paraná (Brasil))
}

\begin{abstract}
This article has as objective the comprehension of the tourist's experience perspective adopted by Jornal Hoje (JH) - Rede Globo on their sketch Tô de Folga (TDF). The conception adopted in this work considers the touristic activities have become an important driver of human dislocations nowadays. And, within this scenery, we analyze one of the top Brazilian TV news programs that maintains an exclusive space dedicated to travels since 2008. The investigation involved a sample involving 44 news pieces and from information gathered through the means of participant's observations and content analysis. In addition, the pairing technique was used. A prevalence of a marketing oriented conception was found - not in the promotional sense, of selling the touristic destination with its attractiveness, experiences and services but of captivating whoever is watching the TV news program first.
\end{abstract}

Keywords: Touristic journalism; Mediatized tourism; Rede Globo; Brazil; Participant observation; Content analysis.

\section{Experiencia turística mediatizada: una concepción de noticiero de la televisión brasileña}

Resumen: Este artículo tiene como objetivo comprender la perspectiva de la experiencia turística adoptada por el Jornal Hoje (JH) - Rede Globo en la sección Tô de Folga (TDF). En el texto se considera que la actividad turística se ha convertido en una importante fuerza inductora de los desplazamientos humanos en la contemporaneidad. En este sentido, analizamos uno de los principales telediarios brasileños, que mantiene un espacio exclusivo dedicado a viajes desde 2008. El proceso de investigación se realizó a partir de una muestra, seleccionando 44 reportajes y datos obtenidos por medio de la observación participante y del análisis de contenido. Además, la técnica de comparación. Los resultados de la investigación permiten constatar que destaca una concepción mercadológica, no en el sentido promocional, es decir, de vender el destino turístico con sus atractivos, experiencias y servicios, sino con el propósito de cautivar principalmente a quien asiste al telediario.

Palabras Clave: Periodismo de turismo; Turismo mediatizado; Rede Globo; Brasil; Observación participante; Análisis de contenido.

\section{Introduction}

The purpose of this article is to document tourism perspective as presented by Jornal Hoje (JH), a program appearing in Rede Globo's network within the sketch Tô de Folga (TDF) which offers spectators tourism destinations. Tourism is considering to be, each time a bit more, object of different types of mass communications means that, from one side, enhance (non)spatialized experiences in physical terms (Mcluhan, 1971; Innerarity, 2010; Moraes \& Rosaneli, 2019) and, from the other side, offer more and more broaden alternative choices by promoting touristic places and spaces (Leung, Law, Hoof \& Buhalis, 2013; Standing, Tang-Taye \& Boyer, 2014; Bosangit, Hibbert \& McCabe, 2015).

In fact, media have become a main reference nowadays, serving as referential for values and behaviors. It is on the media's display that most various discourses and social instances are legitimized and gain visibility, as important works and researches in communication studies have pointed out (Rodrigues,

Universidade Federal do Paraná (Brasil); E-mail: lauromoraes@ufpr.br; https://orcid.org/0000-0003-0836-3941 
1999, 2003; Kellner, 2001; Hjarvard, 2013, 2015). To deny the great influence of means of communications over society is ignoring the own emerging sociability. Because of that, the study of relations between media phenomenon and image focused touristic attractions becomes necessary, in face of the capacity of media to offer a referential framework to the information and content consumers, in general.

This conceptualization is anchored, most of all, in Thompson's (1998) concept of augmented public space, according to which space and time dimensions were completely transformed by the mass media: in order to experience any type of event, spectator doesn't need to be physically at the place where that takes place. The spectator can be at home space and, at the same time, acquire differentiated space-time experiences. This is the most relevant assumption of this article that, starting from tourism news reports shown on TV newscast, disclosures professional practices, mediated destinations, touristic experiences, local culture information and different touristic landscapes. Therefore, the purpose is to discuss a configuration of a society which has in the media an important source of knowledge and references (Kegler \& Froehlich, 2011).

Therefore, $J H$ was delimited as the object of analysis because this newscast holds some particularities amongst the Brazilian newscasts. It is the only one which dedicates an exclusive space to tourism issue. Shown on Fridays, TDF sketch focuses, since December 2008, on national touristic destinations. In general, TDF's proposal is of a service report: in Alviano's words the purpose is (2010, May $3^{\text {rd }}$, personal message) "to show Brazil to Brazilians". The idea is to give to spectator trip options that can be carried out on a weekend, a holiday time or in an extended occasional day off.

It's worth noting that $J H$ is one of the main newscast on Brazilian broadcast television and one of the oldest ones on Rede Globo's schedule, premiering on April 21 ${ }^{\text {st }}$, 1971. It's also shown on TV Globo Internacional (TVGI) that owns seven payed channels devoted to Brazilians, Portuguese and Lusophones living abroad. Existing in every continent, TVGI (2015) has currently more than 3 million customers. According to Temer (2002, p.122): "inside the dynamics of the broadcaster's schedule flow, $[J H]$ corresponds to the after lunch break period of stay-at-home women after finishing lunch". JH's spectator profile is predominantly composed by $\mathrm{C}$ class ( $46 \%)$ people, female $(58 \%$ of the audience being women and adult). $82 \%$ of people watching it are over 25 years of age (Picture 1 ).

Figure 1: Profile of JH's spectators according to age, social class and gender

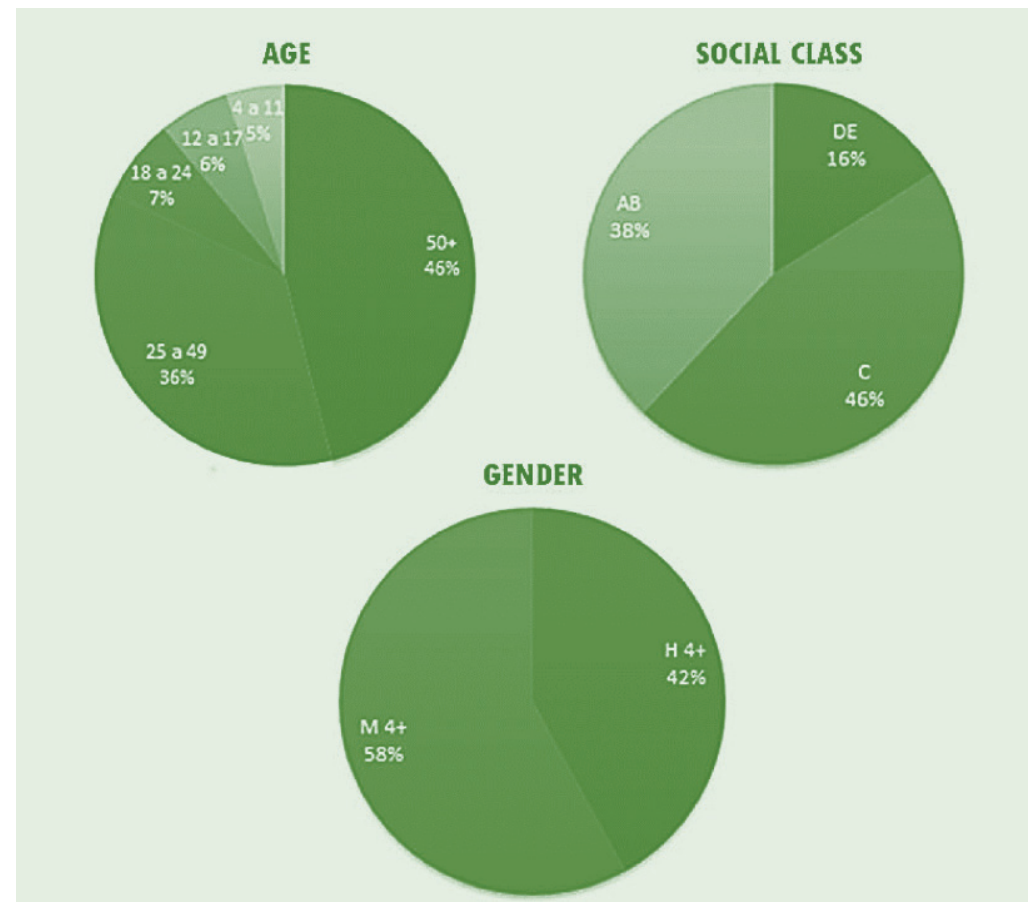

Source: Direção Geral de Negócios (DGN, 2015, Jornal Hoje) 
As for the characteristics of JH, DGN (2015, Jornal Hoje) describes it this way: "Jornal Hoje shows the everyday of cities, information on politics, economy and culture, services, consumer rights and leisure options. Guidelines and special reports are the newscast's strong suits." Among these subjects one can notice a heightened focus on service reports, such as jobs, education, food, domestic economy and tourism.

With the purpose of understanding tourism perspective - and its relationship with journalism and media - adopted by $J H$ we move forward from the following discussion: What sustains the intercultural communication between visitors and hosts? Is the sustainability of the destination a point of view or an experience with promotional and marketing oriented focus? In methodological terms, this study involved the use of participant observation and documental research. A content analysis was done concerning a total of 44 reports. The cross cut of these techniques allowed to analyze the mediation of touristic destinations, the constructions of report as well as the participation the interviewees participation on them.

\section{Mediated interactions: tourism in the age of mediatization}

The exchange of symbolic content information - producing sense, meaning and experiences in the space scope amplified by the media as observed by approaches concerning symbolism inscribed in the marks of publicity discourse (Santos, 2011) - is more intense nowadays especially considering, even if jeopardizing face to face interaction, the spread of mediated interaction contexts (Thompson, 1998, Hjarvard, 2015). And, as Buonanno (2004, p. 340) defends: "There's never been a time that knew a similar explosion of mediated experiences. Great part of our living and knowledge of the world goes through the mediation of the big means of communication."

That means that culture, society and everything that involves it is scripted in the media's own reasoning, and, in the line of what we want to argue in the specific case of this article, in television. With effect, mass media are modifying the way people interact, altering everyday life once they offer "resources available to amplify our imaginary geographies, pluralize our symbolic worlds of life, familiarize us with the other and the distant, build 'imaginary places' senses" (Buonanno, 2004, p. 346).

As already pointed out with regards to tourism, the reader/internet user/spectator doesn't need to be physically in a touristic destination to be able to experience certain experiences. This view about distance and space during a touristic experience is quite clear in Urry (2001, pp. 138-139), who stated the following:

[...] he post-tourist doesn't need to leave the house to see many of the typical objects of a tourists look because thanks to television and video, every type of place can be contemplated, compared, contextualized and again contemplated. It's possible to someone imagine themselves really 'there, see in fact the sunset, the mountain chain or the turquoise blue sea.

Urry (2001) argues that not only certain landscapes and environments but also some people become imaginative constructions which are perpetuated by media actors. And it is media systems that enable expectations and fantasies and motivate touristic movement (Connell, 2005). Thus, media is responsible for creating imaginaries about travels starting from the construction they built on spaces, cultures and destinations historical backgrounds. In other words, tourist destinations are directly impacted by the image evoked through the media (Miossec, 1977, Pearce, 2014).

With effect, recent researches signal internet as one of the most important sources of touristic information (Thomaz, Biz, Bettoni \& Pavan, 2015; Richards, 2009, 2017). Regarding the interference potential of the electronic media on the touristic search, Middleton (2002, p.267) recognizably names television as an "effective in travel and tourism" mean. Such idea stresses the importance of studying $J H$. Connell (2005, p. 764) also observes that mediated touristic exposition can "stimulate interest and alter perceptions concerning the image of the destination". When referring particularly to Rede Globo's journalism, Temer (2002, p. 126) states that: "There is not such a stimulation to a direct consume but it is inevitable that the mention services and news induce stimulation to consume habits, which are identifiable by the valorization of the modern, the technological and in the subjects of tourism".

Therefore, it can be realized that it is a complex field bringing about diverse questionings especially as regards to the dichotomy between neutrality and marketing-logical interests (C. Carvalho, 2003; Destination British Columbia, 2013). With regards to that subject, Vaz (1999, p. 220) presents a definition of tourism journalism that seeks to surpass such opposition: 
Your mission is to bring to the consumer complete and critical information about the product, the most exempt and impartial possible, in a way that the consumer can know the product, evaluate the convenience or not of buying it. It's a function that must be fulfilled by an external observer and his report should obey the rules of journalistic technique, informing, opining and criticizing within a perspective that gives privilege to the rights of the consumer.

The crucial function performed by touristic journalism nowadays should then be pointed out. It responds to the great demand for information regarding travels and itineraries (Avighi, 1992; Moraes, Gândara e Cruz, 2015a). In that sense, A. Carvalho (2007, p. 290) points out that: "touristic journalism, especially because it uses seductive images, awakes or reinforces travelling fantasy". Actually, one can speak about a type of a mediatized tourism, insofar as there are mediatized seduction mechanisms everywhere, from a report until a simple post card.

However, it's necessary to point out that the touristic experience goes beyond the imagined and contemplative dimension. There is "testimony necessity" (Wainberg, 2003, p. 11), because technologies of communication and information but do not promote encounter, face to face interaction, which is only provided by concrete cultural experience (Rodrigues, 1999, 2003). Without this interactional component - the concrete cultural experience - it's not possible to have what is called "tourism of experience", whose proposal is based on the work of Pine II and Gilmore (1999) preconizing that touristic offer needs to aggregate singular sensations that lead to emotion and genuine pleasures, involving emotional, physical, intellectual and even spiritual elements that are able of educating, entertaining and offer an evasion sensation as well as an esthetic fruition (Pulido-Fernández \& Navarro Hermoso, 2014; Valduga, Dartora \& Babinski, 2014; Gândara \& Mondo, 2017; Moraes, Silva \& Gândara, 2018).

That way, paradoxically, media can favor the spectacularization of tourism just as much as the "interactional encounters" once they sustain the spread of traditional touristic scenarios (Gomes, 1996; Debord, 1997; Rubim, 2005; Moraes \& Gândara, 2016a). It can also provide visibility of those that aren't known by the great public, opening a path to the "overcoming of virtuality" (Wainberg, 2003, p. 25). Actually, when structured from a socio-communicational perspective, media "[...] contributes to the view of the tourist that'll come to interact with the community and trade experience with it" (Simões, 2009, p. 67). For that to happen, culture - that can also be understood as a shared experience - needs to be taken as a primordial resource for the economic and touristic development, the "axis of a new epistemic structure", and not as merchandise (Yúdice, 2006, p. 13). In defense of this point of view, Simões (2009, p. 50) states:

To think of the use of culture looking for development through tourism, it's important to point out the material patrimony and the immaterial one, as well as its valorization. In this case, the existing difference in each instance of the cultural patrimony (and also applied to the natural patrimony) goes on to be the recurring currency of negotiation - goes on to be a resource of (author's griffon).

On the contrary, instead of aggregating positive values to touristic action and tourist experience, previous prejudices and stereotypes formed before the trip get stronger, many of which being disseminated and consolidated by media. In regards to this, Urry (2001, p. 29) states:

There the view of certain signs, such as the typical British village, the typical American skyscraper, the typical German brewery, the typical French castle and so on. These ways of looking demonstrate how tourists are, in a certain way, practitioners of semiotics, reading the landscape looking for significant or certain concepts or pre-established signs that derivate from the many discursions of travel and tourism.

Observations confirm that it is an imperative to recognize media's potentialities for anticipating and directing tourist's view, in two senses: in the reductionist sense, like a "roller coaster like" experience (Wainberg, 2003, p. 21) - that is, a fugal, temporary experience, without implications concerning contact with others - or in direction of a broader relationship dimension of the touristic experience, involving all its density, most of all counting with cultural aspects (Banducci Júnior \& Barreto, 2001; Camargo, 2009; Pimentel \& Castrogiovanni, 2015). For example, it was because of tourism that pataxós Indians, in south Bahia, refurbished native language of the tribe and restored rituals as well as traditions that we have almost forgotten. That happened especially through the work being developed in the Ecological Reserve of Jaqueira (Grünewald, 2015). Meanwhile in Rio de Janeiro, there are communities living 
in slums and that started to have economic and environmental gains when they turn out to be also a target of tourism visits (Spampinato, 2009).

These cases in Brazil are evidence of the National Police of Tourism's features that, for an important period, attempted to develop what is considered to be the social function of tourism, seeking to amplify not only touristic offer, but also the level of exchange between visitors, visited places and residents. This policy was demonstrated by the own market segmentation undertaken by Ministry of Tourism (MTur, 2008), by means of which the following types of tourism in Brazil were drawn: Ecotourism, Adventure, Cultural, Studies and Exchange, Nautical, Business and Events, Fishing, Sports, Health, Sun and Beach, Rural and Social. With effect, the visibility of these segments depends on the mediation enacted by means of communications and particularly by journalism (Moraes et al., 2015a). That is, through the news coverage there are more chances of ascertain legitimacy, credibility and trustworthiness to information given about most diverse touristic segments.

\section{A tourism report: infoentertainment narrative}

Journalism as we know it today has its origins in the XIX century and since its beginning, it has included the interest for travels (Falco \& Rodrigues, 2009). The importance that it has on the development of tourism becomes even clearer after the Industrial Revolution that "[...] created or amplified, in the European capitals and principal cities in the United States, affluent and educated social layers, eager for travel and for information regarding their region and world and able to consume them according to their possibilities" (Avighi, 1992, p. 23).

Nowadays, the existence of an expressive number of newspapers and magazines specialized in tourism is noticeable in the Brazilian editorial market, historically recognized as the principal source of touristic information in the country, as well as a large list of travel blogs in the country (Moraes, 2019). Nonetheless, the space devoted to touristic destinations has also grown in television, just as much in newscasts as in themed programs. An example of that is the sketch $T D F$ - the object of this analysis.

Using an expression adopted by García Canclini (2005), Falco (2011, p. 32) sustains that journalist covering this issue can be classified as a specific type of flâneur that "travels and lives the city as if they were a tourist visiting it so later they can report it to the tourist readers". The author shows that touristic journalism is developed form a more informal and subjective perspective, not only concerning its accuracy but also considering the own journalistic narrative. Generally, the "narrator-tourist-reporter" is allowed to expose his/her impressions and sensations, fueling action and movement into the report, making it appear almost as a piece of "infoentertainment" (Kellner, 2003). Nevertheless, Falco (2011, p.35) stresses that this subjectivity arises as "a legitimization aspect of experience being narrated and not as a threat to journalistic objectivity".

This perspective is even more relevant in TV journalism considering that "[...] reporter participates in the action and giving a way of being a mere observer in order to make part of the narrative" (Ferrari \& Sodré 1986, p. 52). Moreover, in touristic journalism, due to its narrative and informal nature, such presence of the reporter becomes even more acute. It emerges then, according to Falco (2011, p. 28), the character of the "narrator-tourist-reporter", "with the intention of leading [spectator]/tourist to an imaginary trip anchored by the own journalistic resources", resembling an exacerbation of the "testimoniality" to which Barbeiro and Lima (2002, p. 95) refer to.

In fact, the ways news concerning the subject of tourism has been constructed, are, in a certain way, a sign of the structural changes which have been taking place as regards television narratives (Musse \& Pernissa, 2010; Silva \& Penteado, 2014). Amongst them, Emerim (2010, p. 11) theorizes the "apparent necessity of entertainment as an indispensable part of television news". And, in fact, the hybridization of format, or, at least, of narrative styles, seems to characterize reports concerning tourism (Moraes, Cruz e Gândara, 2015b).

Despite the main characteristics they are still the ones linked to informative and opinion genres, there are evidences of what Melo (2010, p. 34) terms as diversional genre and also of what the author suggests is a new format, named as "travel history". That is, audiences are looking for more than informative contents on news cast: "[people] look in the means of communication not only for knowledge of the facts that occur in the world but also the entertainment that's so necessary in a way that the imaginary is stimulated, making the fantasy an antidote to resist the disenchantments of your existence" (A. Carvalho, 2007, p. 282). 
Under this perspective about journalist metiér one can notice that there is even more space for the journalist to express his/her once he/she has moved from a condition of being "mediating world facts to the spectators" to be an "actor of the social process" (Emerim, 2010, p. 12), that is, a protagonist of facts being narrated. In a touristic destination, journalist become, many times, a witness/consumer of the products and services being offered, emitting his/her opinion on them, entering the universe of another genre - the opinionative (Melo, 2010, Moraes et al., 2015b).

Following that line of thought, the intended journalistic objectivity approaching touristic news is also questioned by Bignami (2002, p. 69):

News of the newspaper has a direct relationship with the daily fact, besides having a relationship with the interests of the newspaper's market. The tourism report doesn't rely on facts to sell themselves on the market. It finds support in what the location has that's wonderful, or different, to offer to the tourist. It's motivating aspects of the location that end up being part of the report. More than facts, interest the touristic product.

Following that understanding, tourism journalism is devoted to people who are interested in traveling and in knowing places. That is why, the noticeability criteria as outlined by Traquina (2005) is based on positive aspects of destinations. Although, A. Carvalho (2007, p. 283) emphasizes the need of denunciating situations which jeopardize touristic activity: "[...] sometimes, the job of denunciating is fulfilled, for example: reports that critically point to ecological crimes in the name of tourism, incentives to prostitution, predatory activities in certain native communities, reports of cultural assets of significant values, among other."

Brandão (2005) is another author suggesting that news about touristic destinations should consider the respect for the environment and local culture, the reflection and conscientiousness about the positive as well as negative impacts tourism may have on destinations, among other parallel features of touristic activities. The author also notes that focus is another aspect that differentiates tourism reports from the other ones. The basic rule followed in most news is to respond to six fundamental questions (Who? When? What? Where? How? Why?). In touristic news, however, the answer to 'where' and 'why' are highlighted, as the focus is directed to the place as well as the reasons why one should visit this. In this way, tourism journalism plays an important informative role, anticipating relevant data for the tourist, such as the location of the destination, access routes, means of transportation available, what to know in the place visited, accommodation options, food, tours, etc. At the same time, "the role of familiarity in journalism as a place of reference is very noticeable in tourism journalism, which frames the difference by giving it a pleasant, recognizable and non-hostile tone" (Falco, 2011, p. 32).

Therefore, the informative nature of news does not become substantially different when the objects tourism, unless there is any commercial interests interfering in it (C. Carvalho, 2003). It is common offering what is called press trips, used to enchant spontaneous media to certain touristic itineraries (Destination British Columbia, 2013). These travels are funded by Organizations - public or private - associated with touristic market in order to attract the press to visit an asset or destination and when journalists return to the office, it is expected that they "[...] sell histories and images of their stay " (Serviço Brasileiro de Apoio às Micro e Pequenas Empresas - Sebrae, 2010, p. 11).

However, such practice is considered an ethical abnormality, becoming very reductive to assume that reports made by touristic journalism are all subjective or publicity focused. Analyzing specialized magazine Viagem e Turismo, Falco (2011, p. 36) states that:

[...] despite bringing personal impressions to the text, journalists [...] present "auxiliary proofs" to keepsake objectivity. Among these "auxiliary proofs to keepsake objectivity" the presentation always at the end of the information reports very direct to utility and to the reader that's interested in knowing the place reported (as it occurs on the final pages of every report in sections like "Where is it better: eat, stay, go out"; "The essential: where is it, how to get there, who take you, when to go, documents') stand out [...].

This argument underlines again the hybridity of formats as well as of narrative styles that also have a function named by Melo (2010) as "utility" or "service oriented". One can add to this the chances of touristic destinations be presented in a less fragmented way, because, in general, "the service is produced/disseminated with more timey. It weighs on more rigid and almost obligatory quality criteria to the originality and a new focus" (Temer, 2002, p. 37). 
It's in that context that the differentiation between "hot or factual reports" - the ones that, in general, are not foreseen in day agenda setting and need to be immediately released - and "drawer reports" or "cold reports" - that can be used at any moment according to editorial convenience - becomes essential (Rezende, 2000, p. 147; Moraes et al., 2015a). The tourism agendas make commonly part of this second group of reports. One can understand one of the motives by which the reports on this themes suppose a stronger structure of production - from the trails to graphic resources used. These features increase the ability for the newscast to influence touristic search.

\section{Methodology}

We followed a triangular methodological approach, whose application has already been outlined in another articles (Moraes et al., 2015a; Moraes \& Gândara, 2016b). It is supported by content analysis, pattern matching and participant observation techniques, whose methodological process implies to account with the observer as an element making part of the context under observation, also presupposing his/her insertion in a peculiar socio-cultural situation, with the objective of a scientific investigation (Minayo, 2004; Valladares, 2007).

It is worth noting that we had preliminarily developed a bibliographic revision, just as much of works as of articles linked to the theme. This way, the conceptual-theoretical outline that kick started the data approach and analysis was constructed. Due to the lack of references dealing with specialized journalism and tourism, the initial challenge was building a solid theoretical referential by means of crossing contributing coming from works of both areas - tourism and journalism.

The investigation concerning the sketch $T D F$ is complemented with the accompaniment in loco in the redaction of $J H$ in São Paulo. As Geertz (1989) pointed out, men are inseparable from culture and culture shapes behavior. In that sense, the intellectual capacity, fundamental element of the journalistic praxis is incremented by culture and is also enacted in function of it. That is why it is so necessary to immerse - theoretically and methodologically - into the culture of the redactions and of the society in which the journalists work (Hall, Critcher, Jefferson, Clarke \& Roberts, 1993; Traquina, 2005; Moraes et al., 2015a; Moraes \& Gândara, 2016b). Based on this conception, it becomes understandable that the participant observation proposed in this study included more data concerning the period during which of the author of this article for 12 years - half of them in the Globo system - worked as a reporter, editor and presenter. That information allowed to develop a more accurate regard on the routine production at $J H$ - to which, the author even elaborated reports - as itis indicated by Marcon and Elsen when describing the method of data collection during participant observation:

[...] besides constituting a dispositive to obtain detailed information among the informants, it is also a conjunction of behaviors in which the observer is involved. It's objective is to obtain data about the phenomenon in study through direct contacts, in specific situations, in which the resulting distortions of the fact and the researcher can be a strange element that's reduced to minimum. (Marcon \& Elsen, 2000, p. 638)

On this stage the interval of time subjected to the analysis was also delimited - from January 1st to December 31st of 2010 - in order to have information about the entire year, including all the months, what allowed the object to be evaluated more carefully, taking into consideration questions concerning seasonality and newscast's preferences. Then, reports shown on the period were pulled up - most of them available, at the time, on the $J H$ portal, in a specific space devoted to TDF.

The universe of the research encompassed however the content of $J H$ editions in 2010, as well as tall the information collected during participant observation. This way, the sample, defined by Marconi and Lakatos (2001) as a portion or parcel selected from the universe, involved 44 reports from the newscast corresponding to the total number of $T D F$ exhibitions, besides all the observations considered relevant to the study. The analysis was strictly focused on the sketch with tourism focus, insofar as if all the newscasts contents were involved data collection would be too wide, and that would be deviated from the work outline, which was focused on news about tourism, whose focus is exclusive given by TDF.

With effect, material on 44 reports previously recorded/catalogued went through a quality-quantitative preliminary classification. The following categories were then highlighted: destination appearing in newscast, highlighted attractions and touristic segments, main reports' focus, interviewees as well as moments and number of times $T D F$ was not exhibited. With this information brought up, a pilot investigation was done - the first visit to $J H s$ redaction, on days 2 and 3 of August 2010. At this moment, 
the objective was just to know in loco structure, professionals involved as well as understanding, in general, news cast production process in overall and $T D F$, in particular.

The first contact was made possible by the Rede Globo's affiliated coordinator, Marco Antônio Rodrigues who received the author in the broadcaster's headquarters. Then, he accompanied him to the redaction, where he was introduced without formality- treating him as a redaction peer coming from an affiliated broadcaster - to JH's editor chief, Teresa Garcia. This reception enhanced the success of the pilot investigation.

Both, Marcos Antônio Rodrigues and Teresa Garcia, carried on then introducing the author to journalists involved in the production of $J H$. However, as time for scheduled for the meeting had already passed - moment that the redaction chief, producer, schedulers and editors meet to discuss what topics will be dealt with during the day and how these will be approached - it wasn't possible to establish contact with all the professionals immediately. Many of them, including the editor, person in charge for the $T D F$ sketch were on the journalism editing station - place where text, images and interviews are molded, ending up in a television report - that are near to redaction, but in an isolated environment. However, by doing a non-restricted observation focused on journalists work there was no difficulty in making a "self-presentation" to those professionals.

From that point on, it becomes the socio-anthropological approach in the journalistic field which advocates for the observation of members of a redaction in their place of work (Hall et al., 1993). According to Traquina (2005, pp. 171-172) the intention is to "go under the skin' of the people being observed", in order to comprehend journalists attitudes and catching up ideologies, routines and professional practices of those who are producing the news. This way, it is presumed that, besides knowing more deeply the culture that he/she is studying, the researcher takes over it, living it inwardly, making part of its dynamics. Schlesinger (1990) exalts this in loco incursion considering that this procedure allows a more detailed theoretical observation of the journalistic field.

Thus, starting with the understanding that news are produced within their own cultural system, entering that universe contributes decisively to the recognition and the understanding of the routines and professional practices, insofar as, from the point of view of social actors and the meanings they ascribe to objects, phenomenon and actions, it is possible to unfold social phenomenon (Goldenberg, 1997). This perspective is fundamental to affirm journalism constructionist paradigm whose central idea leads to the understanding that news make part of a social construction process of the reality and which has supported many studies done in journalistic field, especially when adopting anthropology and sociology of communication as theoretical and methodological resources (Cramer \& Mcdevitt, 2004; Gastaldo, Leistner, Silva \& McGinity, 2005; Massierer \& Girardi, 2008).

Based on this conception, in loco investigation was done between 11th 15th of July, 2011. At that point, the participant observation was thorough, with a view to collect primary data by accompanying the phase of closing up a text, reports termination and the selection of destinations. These three tasks are under the responsibility of JH's staff. The other tasks - such as interviews, images and edition - are usually scribed to affiliated broadcaster which become responsible covering the touristic destination - the main target of the report.

From the qualitative point of view, we also analyzed two electronic messages which were forwarded by the editor of $T D F$, Wanda Alviano. We had access to it during the period in which author worked in the journalism department of Rede Bahia - Rede Globo's affiliate that covers the state of Bahia, where he performed functions of editor, presenter and reporter, also conducting reports of the TDF sketch. These messages - the first one sent on 11/09/2009 and the second one on 03/05/2010 - contained all the guidelines to be followed in the sketch working as a about what a sketch should contain and how a report should be done. There were also details about the touristic aspects which, from newscast's point of view, should be highlighted; besides other indications of changes during the construction of the text as well as on the structuration of the reports with a view to renew the adopted model when doing the sketch.

Duly noted, these was elementary information obtained from high level confidentiality sources as regards transparency not being constrained by an interviewer/researcher, but to colleagues in the redaction space, in the form of technical and editorial orientation. With effect, these messages next to the bibliographic revision and the information brought up by means of participant observation and the quality and quantity oriented analysis of the reports were able to supply the necessary data to attain the study's objective of presenting the tourism perspective of $J H$ from the sketch TDF.

Composing then, the triangular dimension of the research that advocated the coherent and fundamental methodological plurality, the interpretation of the data capital was given by means of the Content Analysis, understood as "[...] a treatment and analysis of information method collected by means of 
data collection techniques consubstantiated in a document. The technique applies to the written text analysis or any communication there is (oral, visual, sign) reduced to a text or a document" (Chizzoti, 1991, p. 98).

Being adaptable and applicable to the wide field of "communications", linguistics and not linguistics, the complete content analysis is, therefore, the epistemological frame of this study. According to Bardin (1977, p.38) "the content analysis appears as a technique conjunction of communications' analysis that uses systematic procedures and description objectives from the message content". That is why it is an effective method to many areas in the social empirical sciences and often used in tourism research (Rejowski, 2010), as well as communication (Rocha, 2008; Andrade, 2014).

In what abridges the interaction of content analysis with other research techniques, Bardin (1977, p.32) points out that "the more complex, or unstable, or badly explored the code becomes the bigger the effort of the analyst, in the sense of an innovation sighting the elaboration of a new technique". In this case, that was done including instruments of an observational nature, as outlined before, as well as from the technique of pairing (pattern-matching) that allows to "associate the collected data to a theoretical model with the objective of comparing them" (Laville \& Dionne, 1999, p. 227). That way, the empirical evidences collected - statistical and quality information - by means of the reports as well as by direct observation were validated by comparison mean with the theoretical contribution of the research.

Looking to facilitate the pairing between the diverse procedures available by the content analysis, categorical analysis was used, defining it as "[...] a taxonomic method well-conceived to (...) introduce an order according to certain criteria, in the apparent disorder." Therefore, its then established "significant drawers and rubrics that permit the classification of elements of constitutive meaning of the message" (Bardin, 1977, p. 37). Thus, to comprehend the tourism point of view - sustainable or promotional/ market oriented - adopted by $J H$ three categories were defined, objectively:

1) the first one dedicated to edition, text and context of the tourism reports.

2) the other one with a focus to the process of mediatization of the touristic destinations by the newscast.

3 ) and finally, JH's perspective on tourism from interviewees

Through these categories, the totality of "communications" - being it texts, images, testimonials or data collected by direct observation - went through the "[...] classification sieve and the census, according to the presence (or abstinence) frequency of sense items" (Bardin, 1977, p. 37). It emerges then the reason why we choose content analysis, whose flexibility allowed for just as much interpretations of quantitative and subjective order - as well as the comprehension of characteristics and peculiar conducts to $J H$ 's redaction and the journalists involved with the production of the sketch $T D F$ - as quantitative nature, by means of rationalization surrounding numbers and percentages regarding the tourism reports.

\section{Results discussion and analysis}

\subsection{The tourism reports in $J H$ : edition, text and context}

It is observable that the first goal of the reports on the $J H$ is to attract who is watching the television program, which contributes to the promotion of the touristic places and spaces presented (Leung et al., 2013; Standing et al., 2014; Bosangit et al., 2015). That is why, Alviano (2009, November 9th, personal message) states that "script must always be attractive", with "pretty images". This message shows that there are noticeability criteria to select and choose destinations (Vaz, 1999; Bignami, 2002; Falco, 2011; Tranquina, 2005). Furthermore, the text is elaborated following validated techniques of telejournalistic narrative (Rezende, 2000; Melo, 2010; Musse \& Pernissa, 2010; Silva \& Penteado, 2014; Moraes et al., $2015 \mathrm{a}, 2015 \mathrm{~b})$. At the same time, there is the care to avoid repetition and excessive adjectivation, wich go against the view of those who criticize the "publicist" nature of tourism journalism (C. Carvalho, 2003; Destination British Columbia, 2013). That norm did not avoid, however, the appearance of a few buzzwords piece we have analyzed, such as "exuberant nature", "quiet place", "going back in time" and "a good call".

After the reporter having closed the text, it is forwarded by email to the person who is in charge for TDF's edition, in São Paulo, for adjustments and approval. The edition process starts on the local broadcaster from where the schedule suggestion came from and every Thursdays it's terminated by JH's team using trails and graphic resources. That is why, the edition done by the local broadcaster "[...] should be clean, 
with no effects, no music. All the images must come with background soundtrack, ambient sound, ambient audio capture" (Alviano, 2010, May 3rd, personal message). The editor of JH states that:

It's rare, very rare, really rare, to use effects on a network's VT. The rough images, well capitated, show the beauty of the place better than in the fast paced clip. And remembering that: WE NEED EXTRA IMAGES [author's griffon] to place in calls, clips and open under sound in the middle of VT (Alviano, 2010, May 3rd, personal message).

According to what we are saying, this more sophisticated montage is possible because it's a weekly frame and, therefore, has differentiated possibilities for being produced. Anyhow, it demonstrates a more singular treatment of the reports regarding tourism, what potentiates its power of attraction over the audience. However, this "special" character also has its charge. In the cut interval, TDF stopped being transmitted during nine Fridays, which might signalize the production difficulties considering the routines and operational conditions of the respective broadcaster (Temer, 2002).

\section{Table 1: Moments when TDF wasn't shown}

\begin{tabular}{|l|l|}
\hline Date & \multicolumn{1}{|c|}{ Facts on the origin of TDF interruption } \\
\hline $01 / 01$ & Rains in Rion de Janeiro / Angra dos Reis disaster \\
\hline $12 / 02$ & Carnival and the José Roberto Arruda, Federal District governor, case \\
\hline $11 / 06$ & FIFA World Cup \\
\hline $18 / 06$ & FIFA World Cup \\
\hline $25 / 06$ & FIFA World Cup \\
\hline $02 / 07$ & FIFA World Cup \\
\hline $09 / 07$ & FIFA World Cup \\
\hline $26 / 11$ & Organized crime attacks in Rio de Janeiro \\
\hline $31 / 12$ & New Year's eve \\
\hline
\end{tabular}

Source: author

As the tourism reports are usually atemporal - or cold, as Rezende (2000) and Moraes et al. (2015a) argue - that is they are not factual themes needing to be released with urgency, it is common that, in occasional circumstances, they become the first to be cutted out from the newscast. Table 1 presents, exactly, the occasions when this cut was necessary like during the World Cup in South Africa. JH time was reduced almost to half during the competition period, provoking a TDF's interruption. In these conditions, when journalistic routine is altered by and event or extraordinary event, it becomes more improbable to maintain a tourism sketch, what reinforces the role of the noticeability criteria as well as of the competition between them.

\subsection{Mediatized tourism: a Brazilian TV newscast perspective}

Going back thinking of the mediated "contact" with the touristic destinations allowed by JH one knows that it is not complete. Moreover, the goal is not to leave the idea that it substitutes the in loco touristic experience (Moraes \& Gândara, 2016a). The Rede Globo's reports can allow spectator to have moments of entertainment besides giving them relevant information about the places being shown but it is not likely that, by its own, it can promote the same "cognitive and emotional enchantment of the traveler, an enchantment of wider spectrum" (Wainberg, 2003, p. 54).

On the line of what Simões (2009) defined about "virtual travels", the TV newscast can even allow people to travel to distant places, enjoying its attractions using media, in a kind of non-spatialized experience (Mcluhan, 1971; Innerarity, 2010; Moraes \& Rosaneli, 2019). However, "it does not allow [...] physical contact with the place, that is: to try its gastronomy, touch its art, take bath in its waters..." (Simões, 2009, p. 53). It's difficult to imagine a tourism that transcends this "tactile relationship". 
Moreover, as Pine II and Gilmore (1999, p.99) support "the experience is inherently personal [...] and involves emotional, physical, intellectual and even spiritual aspects".

What Rede Globo then does, is to anticipate and orient tourists eyes (Urry, 2001), other than awaken or reinforce the fantasy of travel (A. Carvalho, 2007, p. 290). This way, it acts as a legitimizing source of destinations and media reference in travel, producing sense, meaning and mediated touristic experiences (Kellner, 2001; Kegler \& Froehlich, 2011, Santos, 2011). However, even to those who decide to make the "fantasy" come true after watching a $J H$ report, there is no guarantee that they will be totally conditioned by journalistic narrative. Despite the perception of reality be a product technically elaborated by media, each individual continues, thus, to interpret it according to spontaneous experience frameworks embedded in their own culture (Thompson, 1998; Rodrigues, 1999, 2003; Hjarvard, 2015).

Even if this dialectical relation between the mediated experience and concrete cultural experience, the way $J H$ deals with cultural variables is contradictory. While material patrimony, such as historical constructions, museum's assets, important edifications and monuments were less appreciated, natural attractions, such as fauna, flora, rivers, beaches, mountains, environmental reserves very highlighted. As for the immaterial patrimony, only gastronomy and curiosities associated with touristic destinations deserved more emphasis- that considering the whole sample, thus endorsing higher parts of knowledge, tradition and cultural expressions of places to invisibility (in the $T D F$ sketch). Concerning this, it is worth noting that tourism and culture become each time more complementary and that the quantity of cultural attractions is increasing (Banducci Júnior \& Barreto, 2001; Camargo, 2009, Simões, 2009; Grünewald, 2015;). That suggests the need to balance the evidence ascribed to several elements of cultural patrimony, favoring a wider and heterogeneous view.

We could understand that from the tele journal's point of view, attraction, products and touristic services are not enough. There is a need for them to be objects of mediation, that is, that they go through selection, organization criteria as well as esthetic patterns, amongst other editorial orientations of $J H$, through which "the historical, cultural part can be left to the internet" (Alviano, 2009, November 9, personal message). As regards mediatization, there is another important element behind this position taken by $J H$ - the fact that the discursive practices linked to elements of Ecotourism and Sun and Beach Tourism are simpler than the ones enacted within the field of Cultural Tourism. This has possibly contributed to the inferior position obtained, when comparing to other two segments during the sample's period (Figure 2).

Figure 2: Touristic segments represented on $J H$

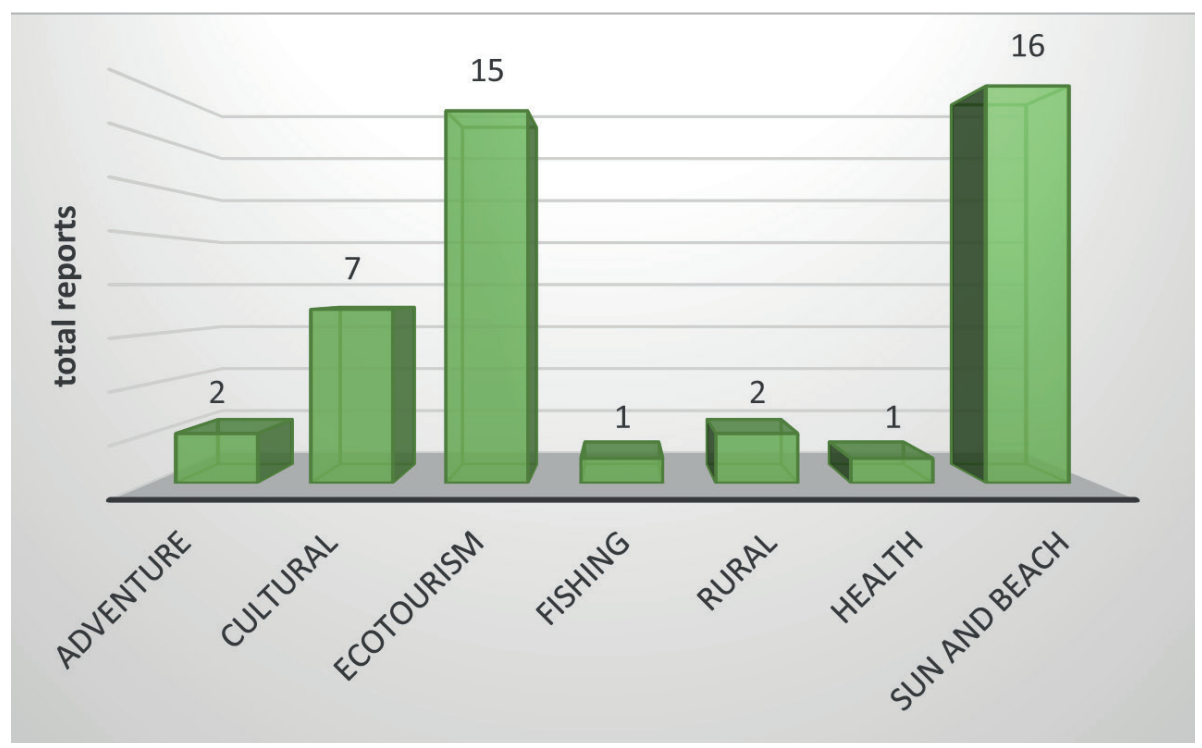

Source: author based on research 
One ought to take into consideration the yet not less important role of spectacularization (Gomes, 1996; Debord, 1997; Kellner, 2003; Rubim; 2005) and which becomes very determinant in mediatization analysis when approaching touristic destinations (Moraes \& Gândara, 2016a). It was so important that all places classified as representing cultural tourism, there was some kind of artistic enactment, or curiosity that was compromised with the spread out of information saying places was or would host some kind of cultural event, what according Richards $(2009,2017)$ defines the good strategies cities use in order to be better positioned within the market of that segment. That is, the treatment of $J H$ as regards cultural tourism is not distinct from the other types of tourism, which, besides informing, intends to, entertain and surprise spectators (A. Carvalho, 2007; Buonanno, 2004; Emerim, 2010,).

With effect, observing touristic attractions stand out by Rede Globo, it was understood that it is more mediated and spectacular to show and talk about "water, sun, beach, ocean, fish, pretty animals, images made underwater, waterfall, lots of food, made tables with lots of attractions, nice hotel, nice inn, comfortable" (Alviano, 2009, November 9, personal message). In the editor responsible for the TDF sketch, these elements would be more attractive than "old churches, historical itineraries, ruins, fallen cities, restored houses, trails that characters walked on (the path made by Dom Pedro, the places the princess went by...), art stores, typical dances and so on [...] (Alviano, 2009, November $9^{\text {th }}$, personal message).

This orientation proves that historical and cultural itineraries might be deprecated insofar as they represent attractions that "aren't very successful" (Alviano, 2009, November 9, personal message). Such understanding puts tourism nearby to what Wainberg (2003, p. 21) denominates "roller coaster like experience". In this perspective culture clearly dealt with it as a product for sale, pasteurized and reduced to mediatized and spectacular aspects (A. Carvalho, 2007; Yúdice, 2006), as JH would not present what the spectator and the potential tourist can access in each destine, but what spectators expect to look at.

Regardless culture elements appear not only in the seven places of the cultural segment but are also highlighted in the two destinations of Rural Tourism - Vassouras/Barra do Piraí (RJ) e Engenhos (PE) - besides the presence in several locations of Ecotourism and Sun and Beach, be it the Cascavel's fair, on the path to Águas Belas beach (CE); in the Serra de Tepequém mines (RR) and in Chapada Diamantina (BA); or in the work of the gum cookies sellers of São Bento (AL). And considering that "almost half of tourists decide to visit a cultural attraction before leaving the house" (Richards, 2009, p. 36 ), the tourism frame on $J H$ can also influence this type of touristic demand. Moreover, particularly in the case of television, that ability is highlighted by Middleton (2002), Temer (2002) and Connell (2005).

In a certain way, it is expected that $\mathrm{JH}$ emphasis locations belonging to Sun and Beach segment that "continues being the principal motivation of tourists" (Camargo, 2009, p. 81). However, the number Ecotourism locations was surprising - 15 touristic destinations were presented- only one less that the number registered concerning Sun and Beach segment. As regards that aspect, one could observe that $J H$ had a strong preservationist worry, following what Brandão (2005) and A. Carvalho (2007) suggests. In several reports, information of environmental nature was underlined, like Serra da Bodoquena's lakes (MS) where feets cannot touch the bottom; a maximum preservation area where dolphins are seen and cannot be touched, in Fernando de Noronha (PE); or the reopening to visitation of Chapada dos Guimarães (MT), interrupted because of the fires that had destroyed part of the reservation.

As the JH's frame proposes exhibit a service VT, the intention is to orient both spectator and the potential tourist, anticipating relevant information to their travel (Alviano, 2010, May $3^{\text {rd }}$, personal message). However, in that case, the orientation of Rede Globo performed an important role with a view to ease tourism impacts on the environment, collaborating with the own sustainability of touristic activities within the places being shown.

\subsection{A tourism perspective from the interviewees}

In what's in respect interviewees on the TDF reports, interviews with tourists had prevailed (65\%), (Figure 3). Representatives of the tourist trade 20\%), from the local community (11\%) and specialists (3\%) complemented this list.

In total, 160 interviews were exhibited - an average mean of 3, 6 interviewees in each report. Fishermen, miners, popular artists, residents, among other representatives of the local community participated in $J H$ with some sort of declaration during the period of the sample. In that scope, however, one notice that little attention was given to people of visited communities. That was only done in fact, in an incisive way in two destinations - Olinda (PE) and São Jose, Maragogi, São Bento (PE/AL). In Turn, the two touristic guides, have excelled themselves from the "trade" representatives. 
Figure 3: Interviewees in TDF's reports, by group

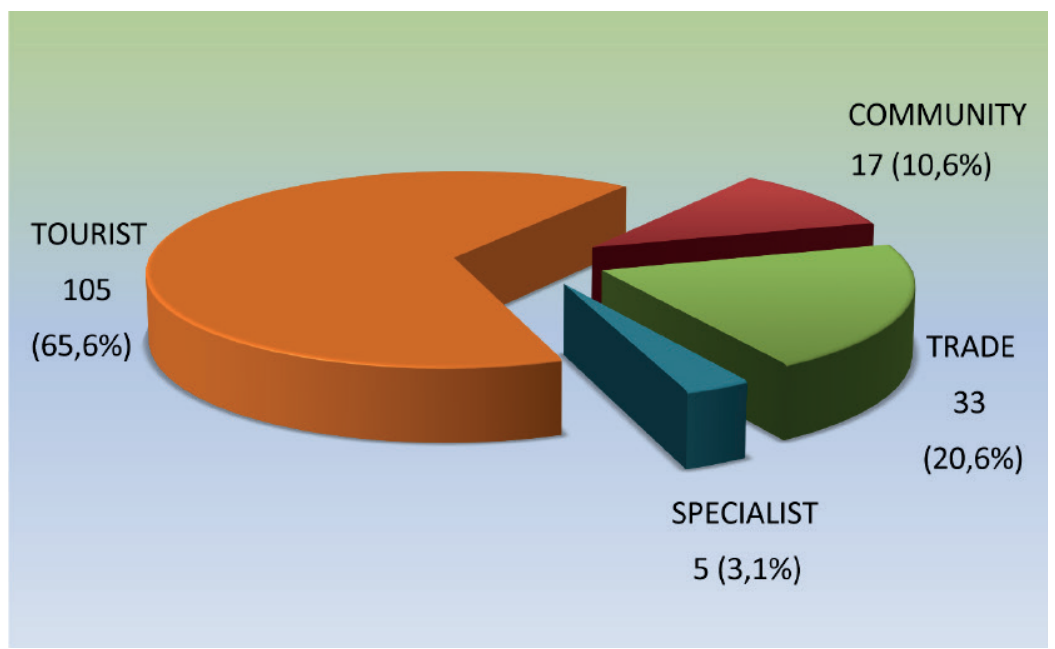

Source: author based on research

And, amongst specialists, two historians, a biologist, an engineer and environmentalist and a geographer were interviewed. In that sense, the TDF edition advises:

If we're going to show a phenomenon - whichever one it is: illuminated ant hill, water that runs upwards, hot water Rivers, sand that reacts to noise, river that's cold in one part, hot in another... Whatever the phenomenon is, we have to tie to a soundtrack of a professor or an explanatory off (Alviano, 2009, November $9^{\text {th }}$, personal message)

According to Temer (2002, p.127) "the specialist researcher gives the knowledge a moral value, dignified by tested, regulated and recognized work (scientific research) by respectable people". However, the only specialist who appeared explaining a phenomenon was a geographer in Tibagi (PR) who clarified the origin of the great holes formed on the rocks through which the waters of a river run. In the other cases in which any other rare phenomenon was shown the explanations was made whether in off or by the presenters, as it had occurred with the thermal waters of Caldas Novas (GO) and with the lagoons where one does not sinks, in Costa Rica (MS). That demonstrates the presence of testimoniality in the journalistic narrative about tourist destinations, as alluded by Ferrari and Sodré (1986); Barbeiro e Lima (2002) and Falco (2011).

During the interviews with tourists, one could notice the use of some clichés as it is common in touristic reports. The tendency was to repeat expressions like "this place is beautiful", "wonderful", "mesmerizing", "you don't feel like leaving". In that sense, Alviano (2009, November 9" message) adds a few other, advising that reporters pay more attention when recording the statements:

Our interviewees say the same thing in almost all VTs: "oh, we come from a big city and get surprised". "Oh, this is paradise". "it's worth it"... Let's ask the tourist to tell how they found out about the place, if they've been here before, what did they like the most, what were they surprised with.

The structure of the interviewees discourses, as well as of the other actors who had been chosen to talk have make even more evident the tourism perspective as knowledgeable and communicated by $T D F$, directing it (the program) to attract people who is watching the newscast, in the first place. The other way round, as the following idea should not make much sense: "The spectator wants to see [...]" (Alviano, 2009, November $9^{\text {th }}$, personal message).

On the other hand, $J H$ itself demonstrated that it is possible to promote the concepts of intercultural communication between visitors and visited, as well as of touristic activity sustainability (Wainberg, 
2003; Simões, 2009), especially considering the way journalistic narrative about de São José (PE), Maragogi (AL) and Japaratinga (AL) was done and edited. Tourists, reporter and local community not only spoke but also had dialogues during the report, showing culture as a singular identity ground (Geertz, 1989) - and, because of that, as a distinguished attraction (Spampinato, 2009; Pimentel \& Castrogiovanni, 2015).

That is evident throughout whole journalistic work: in the interview with a boat and fisherman that, while driving, speaks about the incursion into the mangroves of the place; in the highlight given to the laughter of an owner of a traditional bar, and what is translated by the reporter as "the nicest laugh of the region", as well as to the work of the residents that, according to the report, "live from sweetening the tourists mouths" insofar as they make gum cakes to be sold on the side of the roads.

Within this script, Rede Globo also showed visitors in harmony with nature in a marine preservation area, in Maragogi (AL). Besides the natural beauty, the narrative emphasizes the touristic experience enchantment. Besides it also notes that visits are controlled, done with officers' accompaniment and limited to 600 tourists per day. It also warns about the prohibition of feeding the fish. In this work it is also noted there is a synthesis of good examples. That was surprising considering that it respects to Sun and Beach destination, as the majority of 16 scripts of this segment being presented by TDF had a simpler narrative structure with more emphasis on the stenographic aspects.

This last perspective contradicts, however, the last one, reducing touristic experiences to more diversional or disruptive aspects as regards the regularities, according to categories traced by Gomes (1996) on the basis of the spectacle theory (Debord, 1997). The same occurs with culture when it is ignored in a journalistic report concerning a touristic destination or when superficially treated - only from a dramatized point of view. In that sense, it was noticed that dramatization is a commonly assonated resource used by $J H$ in the reports emphasizing Cultural Tourism.

For example, in Paraty (RJ) there was a staging of Jack Sparrow pirate that would have the role of hosting the tourists where a traditional International Literature Party ids organized; and in Barra do Piraí (RJ) the waitresses of a restaurant in a farm dating from the colonial period play out as slave girls (mucamas), using clothes and adopting behaviors from the slavery period in Brazil, when attending visitors who appear to be fascinated with the experience.

The situations mentioned in the previous paragraph do not express, however, that the reports being referred were superficial or totally dramatized. Nevertheless, they indicate a contemporary trend towards tourism, given that the enacting actions were not suggested by the report team, but by the local touristic offer on its own which, in turn, is based on tourists' desires. In that sense, some authors, such as Pulido-Fernández e Hermoso (2014), Valduga et al. (2014), Gândara \& Mondo, (2017) and Moraes, Silva \& Gândara (2018), among other scholars suggest that contemporary travels need to aggregate emotional marks, surprises, stories, dreams, fantasies, extraordinary living experiences. It is natural that this orientation also influences tourism report, which seeks to enchant the spectator.

\section{Final considerations}

Answering to the research problem proposed in this study, we had observed alternance of tourism perspectives in $J H$. The commercialization conceptualization prevails, not as regards the promotional dimension, of selling tourism destinations with its respective services as products, but as regards the spectator enchantment, of ascribing to reports pleasure and diversion sensations. That is, more than the own value of the place, there is a need to increase or maintain the audience levels. From this perspective, locations inserted in the Sun and Beach as well as Ecotourism segments received a wider space in TV newscast, what can be explained, in most part, due to the ability of these types of tourisms to attract audience's attention.

Concomitantly, it was noted that there is a mutual search - from tourism and specialized journal within this field - for touristic experiences which aggregate emotional marks, surprises, stories, dreams, fantasies, extraordinary living experiences. That is, a tourism based on experience, involving emotional, physical, intellectual and even spiritual elements able of educating, entertaining and offering an evasion sensation as well as an esthetic fruition.

From then on, it was understood that attractions, products and touristic services are in themselves insufficient for $J H$. This is so relevant that cultural variables also turn out to be less prestigious. It is necessary that several aspects of a place are objet of mediatization, going through all the selection criteria stipulated by newscast, and which are not necessarily neither perverse nor negative. Many 
reports, stood out information of an environmental nature, for example. And, even if sustainability is a common label nowadays, the beneficial impact of this criterion cannot be ignored, both as regards environment and tourism itself.

Another aspect to be considered is that the receiving communities as well as local culture go by unnoticed in many reports, and more emphasis is given to generic testimonies emitted by tourists. However, there are some records, which go in opposite direction, promoting the ideas about intercultural communication between visitors and visited, as well as of touristic activity's sustainability. Most of these situations were proposed by reporters from the same country region - Pernambuco - signaling reporter's view is fundamental and decisive to construct both the news and the mediatized destination.

In fact, considering the rhythm to which spaces for touristic journalism increase, it becomes fundamental that sectors linked to touristic activities may establish a professional and constant relationship with press, rejecting attempts of commercial pressure with a view to obtain from media a favorable idea of destination. As demonstrated, Rede Globo's has not as policy to try to sell touristic destinations. From the broadcaster's perspective, a priori, what matters to tv newscast is the spectator: to charm $\mathrm{him} / \mathrm{her}$, entertain him/her and, at the same time, offer him/her a service VT, that is, a tourism report that serves as previous orientation to those who effectively come to visit locations being presented.

Both from the journalistic and sociology of tourism point of view, it is relevant that report has a holistic perspective, approximating the reporter-tourist-narrator not only of touristic destination or tourist but also of the local community, getting involved in their culture, valuing it as an identity feature and not only as a touristic product. That way, journalist will be more able to develop an exploratory curiosity as regards each place attractions, introducing more flavor, texture, smell and color into tourism narratives.

\section{References}

Alviano, W. 2009, 3 may. Tô de Folga. [Mensagem pessoal]. Message received by lauromoraes@redebahia. com.br.

Alviano, W. 2010, 9 nov.. Tô de Folga. [Mensagem pessoal]. Message received by lauromoraes@redebahia. com.br.

Andrade, D. S 2014. A comunicação governamental da presidente Dilma Rousseff: uma análise de conteúdo do portal da Presidência da República. Comunicação e Sociedade, 26, 191-206.

Avighi, C. M. 1992. Turismo e comunicação: estudo do turismo na história da comunicação no séc. XIX. Turismo em Análise, 3, 22-33.

Banducci Júnior, A. \& Barreto, M. (Orgs.). 2001. Turismo e identidade cultural: uma visão antropológica, Campinas: Papirus.

Barbeiro, H. \& Lima, P. R. 2002. Manual de telejornalismo: o segredo da notícia na TV. Rio de Janeiro: Campus.

Bardin, L. 1977. Análise de conteúdo. Lisboa: Edições 70.

Bignami, R. 2002. A imagem do Brasil no turismo: construção, desafios e vantagem competitiva. São Paulo: Aleph.

Bosangit, C., Hibbert, S., \& McCabe, S. 2015. "If I was going to die I should at least be having fun": Travel blogs, meaning and tourist experience. Annals of Tourism Research, 55, pp. 1-14.

Brandão, C. B. 2005. Jornalismo especializado em turismo: foco nas revistas "Horizonte Geográfico", "Os Caminhos da Terra", "Próxima Viagem" e "Viagem e Turismo". In B. C. Castro; G. Alves; M. C. S. Barbosa; A. F. A. Bragança \& S. V. Moreira (Orgs.). Anais do XXVIII Congresso Brasileiro de Ciências da Comunicação (pp. 1-15). São Paulo: Intercom.

Buonanno, M. 2004. Além da proximidade cultural: não contra a identidade, mas a favor da alteridade. Para uma nova teoria crítica dos fluxos televisivos internacionais. In M. I. Lopes, Telenovela: internacionalização e interculturalidade (pp. 331-360). São Paulo: Loyola.

Camargo, P. 2009. Os impactos do turismo cultural. In P. Camargo \& G. Cruz. Turismo cultural: estratégias, sustentabilidade e tendências (pp.69-88). Ilhéus: Editus.

Carvalho, A. L. 2007. O turismo como produto da indústria cultural nas enunciações da mídia. In C. C Paiva, E. B. Barreto \& V. S. Barreto (2007), Mídia \& Culturalidades: análises de produtos, fazeres e interações (pp. 277-297). João Pessoa: Universitária.

Carvalho, C. R. 2003. Jornalismo especializado em turismo: o gênero jornalístico e o mercado nos suplementos de turismo dos jornais Folha de S. Paulo e o Estado de S. Paulo. Master dissertation, University of São Paulo, São Paulo, Brazil.

Chizzoti, A. 1991. Pesquisa em ciências humanas e sociais. São Paulo: Cortez. 
Connell, J. 2005. Toddlers, tourism and Tobermory: Destination marketing issues and television-induced tourism. Tourism Management, 26, 763-776.

Cramer, J. \& Mcdevitt, M. 2004. Ethnographic journalism. In S. Iorio (Ed.), Qualitative research in journalism: taking it to the streets (pp. 127-144). Lawrence Erlbaum, Mahwah.

Debord, G. 1997. A sociedade do espetáculo. Rio de Janeiro: Contraponto.

Destination British Columbia. 2013. Travel Media Relations: The essential guide for BC tourism businesses on how to attract and host media. 3. ed. Victoria, British Columbia, Destination BC.

DGN 2015. Jornal Hoje. Acedido em http://comercial2.redeglobo.com.br/programacao/Pages/JornalHoje. aspx\#l

Emerim, C. 2010. O texto na reportagem de televisão. In M. C., Barbosa, M. C. S. Barbosa; M. V. Gonçalves (Orgs.). Anais do XXXIII Congresso Brasileiro de Ciências da Comunicação (pp. 01-15). São Paulo: Intercom.

Falco, D. 2011. Narrativas turísticas: imaginário e mídia na experiência urbana do turismo. Rosa dos Ventos, 3, 24-38.

Falco, D. P.; Rodrigues, M. C. 2009. Uma jornada pela produção jornalística em suas interações com o turismo: reflexões sobre a revista Viagem \& Turismo. In: Coutinho, I.; Leal, P. R. F. (Orgs.). Identidades midiáticas: memória e representação. Rio de Janeiro: E-papers, pp. 43-57.

Ferrari, M. H. \& Sodré, M. 1986. Técnica de reportagem: notas sobre a narrativa jornalística. São Paulo: Summus.

Gândara, J. M., Mondo, T. S. 2017. O turismo experiencial a partir de uma perspectiva socioeconômica mercadológica. Revista de Análisis Turístico, 24, pp. 26-40.

García Canclini, N. 2005. Consumidores e cidadãos: conflitos multiculturais da globalização. 5. ed. Rio de Janeiro, UFRJ.

Gastaldo, E. L.; Leistner, R. M.; Silva, R. T. \& Mcginity, S. 2005. Futebol, mídia e sociabilidade: uma experiência etnográfica. Cadernos IHU Idéias, 43,1-20.

Geertz, C. (1989). A interpretação das culturas. Rio de Janeiro: LTC.

Goldenberg, M. 1997. A arte de pesquisar: como fazer uma pesquisa qualitativa em Ciências Sociais. Rio de Janeiro: Record.

Gomes, W. S. 1996. Duas premissas para a compreensão da política espetáculo. In A. F. Neto; M. J. Pinto (Orgs.), O indivíduo e as mídias (pp.30-46). Rio de Janeiro: Diadorim.

Grünewald, R. A. 2015. Turismo na terra indígena Pataxó de Coroa Vermelha: imperialismo e pós -colonialidade na região do Descobrimento do Brasil. PASOS - Revista de Turismo y Patrimonio Cultural, 13, 411-424.

Hall, S.; Critcher, C., Jefferson, T., Clarke, J. \& Roberts, B. 1993. A produção social das notícias: o muggin nos media. In N. Traquina (Org.), Jornalismo: questões, teorias e estórias (pp. 224-262). Veja: Lisboa.

Hjarvard, S. 2013. Midiatização: teorizando a mídia como agente de mudança social e cultural. Matrizes, 5(2), pp. 53-91.

Hjarvard, S. 2015. Da Mediação à Midiatização: a institucionalização das novas mídias. Parágrafo, 2(3), pp. 51-62.

Innerarity, D. 2010. O novo espaço público. Lisboa: Texto Editores.

Kegler, J. Q. S. \& Froehlich, J. M. 2011. Midiatização e identidade territorial: pressupostos teóricos para a análise das festividades e seus processos de mediação como construtores da identidade territorial no Brasil Meridional. Mediaciones Sociales, 8, 97-124.

Kellner, D. 2001. A cultura da mídia. São Paulo: Edusc.

Kellner, D. 2003. A cultura da mídia e o triunfo do espetáculo. Líbero, 11, 4-15.

Laville, C. \& Dionne, J. (1999). A construção do saber: manual de metodologia da pesquisa em ciências humanas. Belo Horizonte: UFMG.

Leung, D., Law, R., Hoof, H., \& Buhalis, D. 2013. Social Media in Tourism and Hospitality: A Literature Review. Journal of Travel \& Tourism Marketing, 30(1-2), pp. 3-22.

Marcon, S. S. \& Elsen, I. 2000. Estudo qualitativo utilizando observação participante - análise de uma experiência. Acta Scientiarum, 22, 637-647.

Marconi, M. A. \& Lakatos, E. M. 2001. Metodologia do trabalho científico. São Paulo: Atlas.

Massierer, C. \& Girardi, I. M. T. 2008. O peso da organização jornalística na construção das matérias de meio ambiente no Brasil, In G. Cimadevilla (Org.), Comunicación, tecnologia y desarrollo - trayectorias (pp. 45-58). Rio Cuarto: Universidad Nacional de Rio Cuarto.

Mcluhan, M. 1971. Os meios de comunicação como extensões do homem (3. ed ed.). São Paulo: Cultrix. 
Melo, J. M. 2010. Gêneros jornalísticos: conhecimento brasileiro. In J. M. Melo \& F. Assis, Gêneros jornalísticos no Brasil (pp. 23-41). São Bernardo do Campo: Umesp.

Middleton, V. T. 2002. Marketing de turismo: teoria e prática. Rio de Janeiro: Campus.

Minayo, M. C. S. 2004. O desafio do conhecimento: pesquisa qualitativa e em saúde. Hucitec, São Paulo.

Moraes, L. A., \& Gândara, J. M. 2016a. Midiatização e espetacularização do turismo. Turismo \& Sociedade, 9(1), pp. 1-18.

Moraes, L. A., \& Gândara, J. M. 2016b. Viajando através do Jornal Hoje: os destinos turísticos do "Tô de Folga". Revista Fronteiras - estudos midiáticos, 18(2), pp. 208-224.

Moraes, L. A., Gândara, J. M., \& Cruz, G. 2015a. Turismo midiatizado: o que é notícia nos destinos turísticos apresentados pelo Jornal Hoje, da Rede Globo. Conexão (UCS), 14(27), pp. 47-79.

Moraes, L. A., Cruz, G. \& Gândara, J. M. 2015b. Tourism News: reflexões sobre construção da notícia e narrativa televisiva de destinos turísticos. Rosa dos Ventos,7(1), pp. 87-103.

Moraes, L. A., Gândara, J. M \& Silva, S. R. X. 2018. Geografia urbana setecentista e turismo: as praças de Mariana - Brasil sob a perspectiva experiencial. Pasos - Revista de Turismo y Patrimonio Cultural, 16(4), pp. 971-988.

Moraes, L.A. 2019. Cibercultura e Turismo: em busca do ethos e perfil dos blogs de viagem no Brasil. Rosa dos Ventos - Turismo e Hospitalidade, 11(4), pp. 893-907.

MTur 2008. Segmentação do turismo: orientações básicas. Brasília: MTur.

Musse, C. F. \& Pernisa, M. B. (2011). Telejornalismo: novos formatos no cenário de crise da TV aberta. Revista ALTERJOR, 1(3), pp. 1-12.

Pimentel, M. R. \& Castrogiovanni, A. C. 2015. Geografia e Turismo: em busca de uma interação complexa. Rosa dos Ventos, 7(3), pp. 440-458.

Pine II, J. \& Gilmore, J. The experience economy. Boston: HBS Press, 1999.

Pulido-Fernández, J. I. \& Navarro Hermoso, Ú. 2014. Identificación de ítems para medir las experiências. Cultur, 8, 4-34.

Rejowski, M. 2010. Produção Científica em Turismo: análise de estudos referenciais no exterior. Turismo em Análise, 21(2), pp. 224-246.

Rezende, G. J. 2000. Telejornalismo no Brasil. São Paulo: Summus.

Richards, G. 2009. Turismo cultural: padrões e implicações. In P. Camargo, \& G. Cruz, Turismo cultural: estratégias, sustentabilidade e tendências (pp. 25-48). Ilhéus: Editus.

Richards, G. 2017. Sharing the New Localities of Tourism. In: Dredge, D.; Gyimóthy, S. (Eds.), Collaborative Economy and Tourism: Perspectives, Politics, Policies and Prospects. Dordrecht, Springer, pp. 169-184.

Rocha, S. M. 2008. Análise de conteúdo articulada à análise de gênero televisivo: proposta metodológica para interpretação das representações nas narrativas mediáticas. revista Fronteiras - estudos midiáticos, 10(2), pp. 121-134.

Rodrigues, A. D. 1999. Comunicação e cultura: a experiência cultural na era da informação. Lisboa: Editorial Presença.

Rodrigues, A. D. 2003. A experiência técnica. Revista da Faculdade de Ciências Sociais e Humanas, 15, pp. 9-33.

Rubim, A. A. C. 2005. Espetáculo. In A. A. C. Rubim (Org.), Cultura e atualidade (p.11-28). Salvador: EDUFBA.

Santos, C. 2011. O simbolismo das marcas no discurso publicitário contemporâneo. O capital simbólico da YORN. Comunicação e Sociedade, 19, 215-226.

Schlesinger, P. 1990. Rethinking the sociology of journalism: source strategies and the limits of media centrism. In M. Ferguson (Org.), Public communication: the new imperatives (pp. 61-83). Sage Publications: London.

Sebrae 2010. Turismo no Brasil: termo de referência para a atuação do sistema Sebrae. Brasília: Sebrae.

Silva E.C.; Penteado, R.Z. (2014) Caracterização das inovações do telejornalismo e a expressividade dos apresentadores. Audiology - Communication Research, 19(1), pp. 61-68.

Simões, M. 2009. Identidade cultural e turismo: a literatura como agenciadora de trânsitos. In P. Camargo \& G. Cruz (Orgs.), Turismo cultural: estratégias, sustentabilidade e tendências (pp. 49-67). Ilhéus: Editus.

Spampinato, E. 2009. Turismo em favelas cariocas e desenvolvimento situado: a possibilidade do encontro em seis iniciativas comunitárias. Master dissertation, Federal University of Rio de Janeiro, Rio de Janeiro, Brazil.

Standing, C., Tang-Taye, J.-P., \& Boyer, M. 2014. The Impact of the Internet in Travel and Tourism: A Research Review 2001-2010. Journal of Travel \& Tourism Marketing, 31(1), pp. 82-113. 
Temer, A. C. 2002. Notícias e serviços: um estudo sobre o conteúdo dos telejornais da Rede Globo. Comunicação \& Sociedade, 37, 115-134.

Thomaz, G. M.; Biz, A. A.; Bettoni, E. M. \& Pavan, C. S. 2015. Modelo de monitoreo de las redes sociales para orientar en la toma de decisiones de las Destination Management Organizations. Revista Brasileira de Pesquisa em Turismo, 9(2), pp. 196-220.

Thompson, J. B. 1998. A mídia e a modernidade. Petrópolis: Vozes.

Traquina, N. 2005. Teorias do Jornalismo: porque as notícias são como são. Florianópolis: Insular.

TVGI 2015. Institucional. Acedido em http://tvglobointernacional.globo.com/institucional.aspx/

Urry, J. 2001. O olhar do turista: lazer e viagens nas sociedades contemporâneas. São Paulo: Nobel.

Valduga, V.; Dartora, J. S. \& Babinski, L. R. (2014). A cachaça e o turismo no território do vinho: Rio Grande do Sul (Brasil). Revista Hospitalidade, 11, 195-222.

Valladares, L. 2007. Os dez mandamentos da observação participante. Revista Brasileira de Ciências Sociais, 22(63), pp. 153-155.

Vaz, G. N. 1999. Marketing turístico: receptivo e emissivo. São Paulo: Pioneira.

Wainberg, J. 2003. Turismo e Comunicação: a indústria da diferença. São Paulo: Contexto.

Yúdice, G. 2006. A conveniência da cultura: usos da cultura na era global. Belo Horizonte: UFMG.

\title{
Notes
}

1 This article presents fragments of the author's doctoral thesis in Geography discussions, to be defended at the Federal University of Paraná in 2020.

Acknowledgment: the author is grateful to Fernanda Santana for her support in writing and revising the text in English and to Prof. José Gândara (in memorian) for the invaluable contributions.

\section{Appendix: Brazilian states abbreviations cited}

\author{
AL - Alagoas \\ BA - Bahia \\ CE - Ceará \\ GO - Goiás \\ MS - Mato Grosso do Sul \\ MT - Mato Grosso \\ PE - Pernambuco \\ PR - Paraná \\ RJ - Rio de Janeiro \\ $\mathrm{RR}$ - Roraima
}

